\title{
Contribution to the Red List of Pakistan: a case study of the narrow endemic Silene Iongisepala (Caryophyllaceae)
}

\author{
HA I D A R A L I and M. QA ISER
}

\begin{abstract}
Silene longisepala Nasir (Caryophyllaceae) is a plant endemic to Chitral District in mountainous northwest Pakistan. This taxon was previously known from only two localities. In field studies during 2005-2007, 24 new localities in lower Chitral were discovered. We found 608 mature individual plants in 22 localities in 2005, 520 mature individuals in 17 localities in 2006, and 531 mature individuals in 18 localities in 2007. Considering the population size in 2007 , an extent of occurrence of $3,587 \mathrm{~km}^{2}$ and area of occupancy of $104 \mathrm{~km}^{2}$, we recommend that the species is categorized as Endangered on the IUCN Red List. The main threat to the species is habitat destruction from road construction, land conversion for agriculture and soil erosion following deforestation; we witnessed the direct effects of these pressures on S. longisepala during our fieldwork. In some localities, however, S. longisepala is fortuitously protected by the general inaccessibility of its habitat. There is no legal framework in Pakistan for the protection of rare and endemic plant taxa on private lands and therefore ex situ conservation may be required for narrow endemics such as $S$. longisepala. Our methodology in this study, in which we combined detailed field surveys with monitoring, could form a model for conservation research on rare and endemic plant taxa in Pakistan and elsewhere.
\end{abstract}

Keywords Caryophyllaceae, conservation status, Chitral, Endangered, narrow endemic, Pakistan, Red List, Silene longisepala

\section{Introduction}

$\mathrm{D}$ ocumenting plant diversity was the first of the 16 targets for 2010 (Callmander et al., 2005) adopted by the sixth Conference of the Parties to the Convention on Biological Diversity. The total number of identified vascular plant species is estimated to be between 310,000 (Prance et al., 2000) and 420,000 (Bramwell et al., 2002). The 2010 Red List (IUCN,

HaIDAR Ali (Corresponding author) Department of Weed Science, KPK Agricultural University Peshawar, 25130-Peshawar, Pakistan. E-mail alibotanist@yahoo.com

M. QAISER Federal Urdu University for Arts, Science and Technology, Islamabad, Pakistan

Received 18 April 2010. Revision requested 14 June 2010.

Accepted 20 July 2010.
2010) contains $>12$,000 plant taxa but $<1,000$ are properly documented ( $<8.3 \%$ of global plant diversity). The process of conservation assessments clearly needs to be accelerated.

A total of 1,572 genera and 5,521 species of flowering plants have been documented for Pakistan (Ali, 2008) but there is no comprehensive national Red List. The pressures on plants and other wildlife are, however, considerable, with a human population increasing annually at a rate of $2.1 \%$ (The World Bank, 2011), unplanned urbanization, deforestation and overexploitation of natural resources (Ali, 2000; Anon., 2000; Sheikh et al., 2002; Ahmad et al., 2005; Eberhardt et al., 2006; Schickhoff, 2006). There has been little research on the threatened plants of Pakistan (Alam \& Ali, 2009; Ali \& Qaiser, 2010a,b). A herbariumbased study (Nasir, 1991) suggested that 580-650 species of flowering plant (i.e. c. $12 \%$ of the total flora) are threatened nationally. However, this assessment was not based on any criteria. Fourteen flowering plant species were listed as threatened in Pakistan by Walter \& Gillet (1998). In the 2010 Red List (IUCN, 2010), only 26 species of plants are listed from Pakistan. This is almost certainly an underestimate.

Ibrar (2003) assessed the conservation status of eight Himalayan medicinal plants in Pakistan but his approach was based on availability in markets and consumption (i.e. data on population size, extent of occurrence and area of occupancy was not obtained). To determine the conservation status of a taxon it is necessary to monitor population size, determine the extent of occurrence and area of occupancy, and the nature and extent of any threats (IUCN, 2001). Endemic taxa merit special attention because of their limited geographical distribution; any unfavourable change in habitat may cause the rapid extinction of such species (Callmander et al., 2005). In addition, endemic and rare species are of particular value from an evolutionary point of view.

There is a particular need for botanical research in the biodiverse mountain areas of Pakistan. About $80 \%$ of the endemic flowering plants of the country (of a total of 410 taxa) are confined to the northern and western mountains of Pakistan and Kashmir (Ali, 2008). Within this region the area of Chitral has 34 known endemic species and is recognized as a centre of plant radiation (Ali \& Qaiser, 1986).

One of these endemic plant species is Silene longisepala E. Nasir of the family Caryophyllaceae. The species was 
previously known from only three collections in two localities (Table 1). The aim of the present study was to determine the geographical distribution of $S$. longisepala, evaluate its conservation status, identify any threats, and recommend conservation measures.

\section{Methods}

Field studies were conducted during 19 May 2005 to 30 September 2005, 1 May to 30 September 2006 and 1 June to 30 September 2007. Chitral, with an area of $14,850 \mathrm{~km}^{2}$, is the largest district of the North-West Frontier Province of Pakistan (Anon., 1998). We carried out field surveys in lower Chitral in May and June and upper Chitral from July to the end of September. In excursions of 7-10 days we visited localities from where the taxon had previously been collected and localities that had not previously been surveyed but that lie within the altitudinal range and habitat typical of $S$. longisepala. The excursions were conducted with the help of local guides and porters, using horses or yaks for transportation. The routes followed were recorded with a global positioning system, altimeter and 1:50,000 maps from the survey of Pakistan.

When a population of the species was located 1-2 days were spent in the location to determine the extent of the population by walking within an area of at least $1-2 \mathrm{~km}^{2}$ in each locality. The number of mature individuals (i.e. with fruits or flowers) was counted. Comprehensive field notes on habit, habitat, life form, phenology and altitudinal range of the species were recorded. Any anthropogenic threats (grazing, expansion of agriculture, road building and deforestation) were recorded, and the number of individual plants apparently grazed was counted. Plant specimens collected were deposited at Karachi University Herbarium (KUH).

To determine the extent of occurrence (the area contained within the shortest continuous imaginary boundary that can be drawn to encompass all the known sites of occurrence of a taxon, excluding cases of vagrancy) of the species the geographical coordinates of each S. longisepala located were plotted on georeferenced imagery, obtained from Google (2009), using ArcView v. 3.2 (ESRI, Redlands, USA) and a polygon drawn to encompass all the known localities of the taxon. Area of occurrence (the area within the extent of occurrence that is occupied by a taxon) was calculated by overlaying a grid of $2 \times 2 \mathrm{~km}$ squares on the distribution map and summing the area of the squares in which the species was located. The conservation status of S. longisepala was assessed using the IUCN Red List criteria (2001).

\section{Results}

We found S. longisepala in 24 previously unrecorded localities (Table 1), mostly in rock crevices (Plate 1), at altitudes of $1,554-2,416 \mathrm{~m}$. We observed that the species is
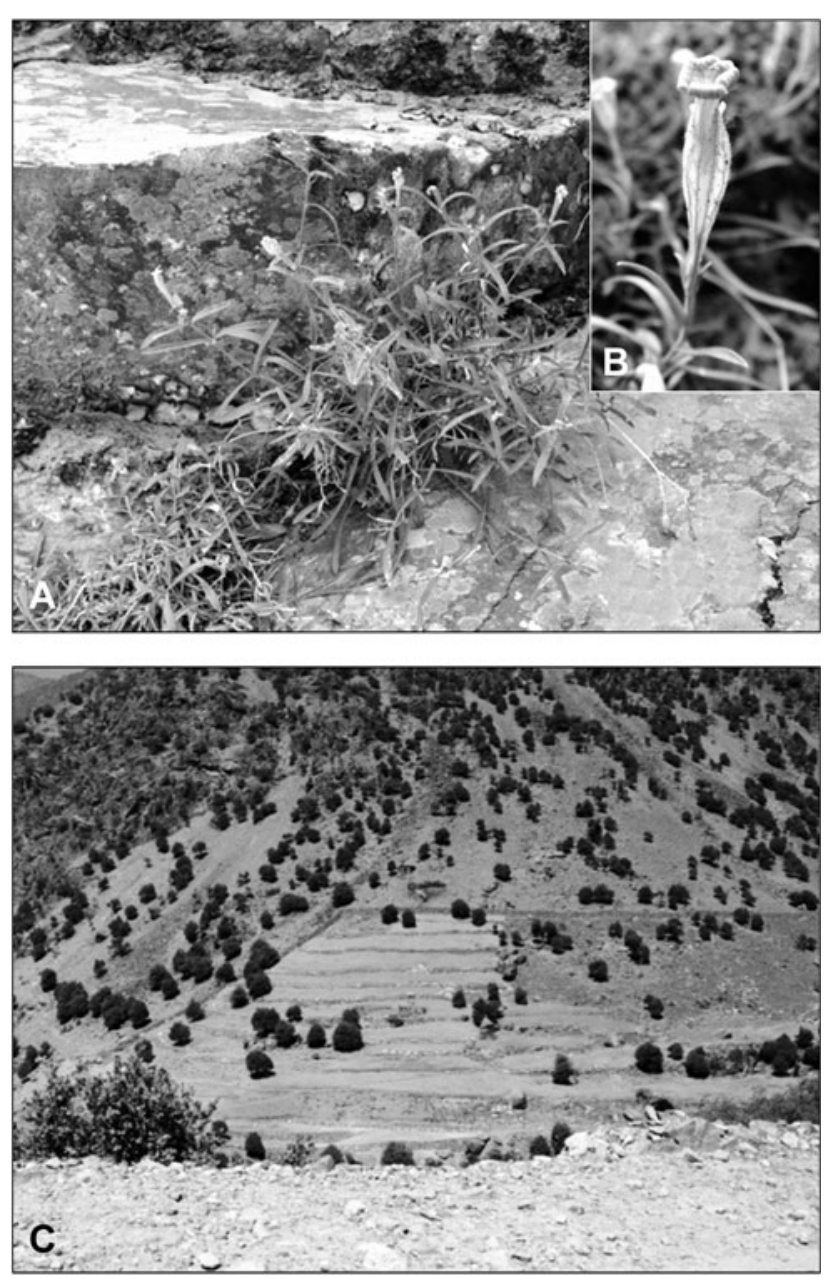

Plate 1 (a) Habit and (b) flower of Silene longisepala. (c) Expanding cultivation on marginal lands is a threat to the wild flora in general and to S. longisepala in particular.

a chamaephyte (following Raunkiaer, 1934), with a height of 20-30 cm (Table 1). We observed flowering and fruiting in August. We found only one small population of S. longisepala in a protected area (Location 3, Chitral Gol National Park; Fig. 1, Table 1). Although Chitral Gol is a National Park of IUCN category II (IUCN, 2000) we found that $S$. longisepala had been grazed there (Table 1). Considering all 26 sites, 15,31 and $24 \%$ of the plants we located were grazed in 2005, 2006 and 2007, respectively (Table 1). We observed the plants being grazed by goats and sheep.

Road construction and subsequent soil erosion is a threat to the habitat of $S$. longisepala. In the two locations where we observed such construction (Plate 2) the populations decreased by $69 \%$ from 2005 to 2007 in Suratwet-Rumboor (Location 10) and by 25\% from 2006 to 2007 in MegegramBakhtooli (Location 15; Fig. 1, Table 1). Because of the mountainous topography and narrow valleys land for agriculture is limited in this area but new areas are still being cleared and brought under cultivation. In Owyon Ghari (Location 7), where we found S. longisepala in 2005 
TABLE 1 The 26 localities (see Fig. 1 for the 18 numbered locations in which the species was found in 2007) in which we found Silene longisepala, with habitat, location in UTM coordinates, altitude, and population size and number of grazed plants in 2005,2006 and 2007. The two footnotes indicate the three collections, in two localities, from which the species was previously known.

\begin{tabular}{|c|c|c|c|c|c|c|c|c|c|}
\hline \multirow[b]{2}{*}{ Locality } & \multirow[b]{2}{*}{ Habitat } & \multirow[b]{2}{*}{ Location } & \multirow{2}{*}{$\begin{array}{l}\text { Altitude } \\
(\mathrm{m})\end{array}$} & \multicolumn{3}{|c|}{ Population size } & \multicolumn{3}{|c|}{ No. of grazed plants } \\
\hline & & & & 2005 & 2006 & 2007 & 2005 & 2006 & 2007 \\
\hline $\begin{array}{l}\text { 1, Chitral, Beshgram on } \\
\text { way to Sosoom }\end{array}$ & $\begin{array}{l}\text { Rocky steep } \\
\text { slope }\end{array}$ & $42-400001$ E $7976449 \mathrm{~N}$ & 2,000 & 19 & 4 & & & & \\
\hline 2, Chitral, Danin Gol & Rock crevice & $42-754002$ E $3972818 \mathrm{~N}$ & 1,950 & 53 & 12 & & & & \\
\hline $\begin{array}{l}\text { 3, Chitral, Gokhshal on } \\
\text { way to Kasaweer }\end{array}$ & Rock crevice & $42-743159$ E $3975996 \mathrm{~N}$ & 2,700 & 29 & 30 & 50 & 20 & 8 & 19 \\
\hline $\begin{array}{l}\text { 4, Chitral, Gorapon } \\
\text { towards Kalash }\end{array}$ & Rock crevice & $42-748248$ E $3957216 \mathrm{~N}$ & 1,540 & 7 & & & & & \\
\hline $\begin{array}{l}\text { 5, Chitral, Joghor Gol } \\
\text { Ghari }^{1}\end{array}$ & Rock crevice & $42-752704$ E $3967373 \mathrm{~N}$ & 1,774 & 2 & & & & & \\
\hline $\begin{array}{l}\text { 6, Chitral, Mojegan } \\
\text { Arkari }\end{array}$ & Rock crevice & $42-743438$ E $3993856 \mathrm{~N}$ & 2,140 & 7 & & & & & \\
\hline 7, Chitral, Owyon Ghari & Rock crevice & $42-748250$ E $3957226 \mathrm{~N}$ & 1,554 & 21 & 40 & & & & \\
\hline 8, Chitral, Pasti Ghari & Rock crevice & $42-769937$ E $3996524 \mathrm{~N}$ & 2,169 & 21 & & 21 & 12 & 6 & \\
\hline $\begin{array}{l}\text { 9, Chitral, Riri Chatho } \\
\text { Ghari }\end{array}$ & $\begin{array}{l}\text { Undulating } \\
\text { gentle grassy } \\
\text { slope }\end{array}$ & $43-232768$ E $4001081 \mathrm{~N}$ & 2,766 & 14 & & 14 & & & \\
\hline $\begin{array}{l}\text { 10, Chitral, Suratwet } \\
\text { Rumboor }\end{array}$ & Rock crevice & $42-742172$ E $3963227 \mathrm{~N}$ & 2,028 & 39 & 21 & 12 & 23 & 7 & \\
\hline 11, Lutkhoo, Arkari Momi & Rock crevice & $42-754997$ E $3988804 \mathrm{~N}$ & 2,053 & 36 & 30 & 19 & & 3 & 7 \\
\hline 12, Lutkhoo, Bakhtooli Gol & Rock crevice & 42-755927 E $3990759 \mathrm{~N}$ & 2,510 & & 39 & 17 & & 10 & 13 \\
\hline $\begin{array}{l}\text { 13, Lutkhoo, Buzur hill, } \\
\text { Shasaleem }\end{array}$ & $\begin{array}{l}\text { Rocky steep } \\
\text { slope }\end{array}$ & $42-723422$ E $3984737 \mathrm{~N}$ & 3,200 & & & 29 & & & \\
\hline $\begin{array}{l}\text { 14, Lutkhoo, Degheri Shah } \\
\text { Saleem }\end{array}$ & Rocky crevice & $43-712576$ E $3994319 \mathrm{~N}$ & 3,045 & 7 & & & & & \\
\hline $\begin{array}{l}\text { 15, Lutkhoo, Megegram } \\
\text { Bakhtooli }\end{array}$ & Rock crevice & $42-741043$ E $3999929 \mathrm{~N}$ & 2,275 & & 80 & 60 & & 42 & 48 \\
\hline $\begin{array}{l}\text { 16, Lutkhoo, Mogh towards } \\
\text { Garm chashma }\end{array}$ & $\begin{array}{l}\text { Rocky steep } \\
\text { slope }\end{array}$ & $42-737209$ E $3988151 \mathrm{~N}$ & 2,049 & & 70 & 32 & & 41 & \\
\hline $\begin{array}{l}\text { 17, Lutkhoo, Sewakht } \\
\text { Shoghore }\end{array}$ & Rock crevice & $42-752641$ E $3996145 \mathrm{~N}$ & 2,586 & 21 & 6 & 18 & 2 & 1 & 17 \\
\hline 18, Mastooj Parwak & Rock crevice & $43-269727$ E $4017540 \mathrm{~N}$ & 2,230 & 54 & 39 & & 23 & 21 & \\
\hline $\begin{array}{l}\text { 19, Mastooj, Booni } \\
\text { Gol Ghari }\end{array}$ & $\begin{array}{l}\text { Undulating } \\
\text { steep rocky } \\
\text { slope }\end{array}$ & $43-253733$ E $4017793 \mathrm{~N}$ & 2,092 & 19 & 5 & 42 & & & \\
\hline $\begin{array}{l}\text { 20, Mastooj, Chowinch } \\
\text { Ghari }\end{array}$ & $\begin{array}{l}\text { Rocky steep } \\
\text { slope }\end{array}$ & $37-410168$ E $8054306 \mathrm{~N}$ & 2,800 & 11 & 31 & 48 & 2 & 12 & 7 \\
\hline $\begin{array}{l}\text { 21, Mastooj, Near Sanoghur } \\
\text { bridge }\end{array}$ & Rock crevice & $43-269749$ E $4017401 \mathrm{~N}$ & 2,263 & 24 & 20 & 36 & & & \\
\hline $\begin{array}{l}\text { 22, Molikhoo, } 2 \mathrm{~km} \text { from } \\
\mathrm{N} \text { on way to Tirich }\end{array}$ & $\begin{array}{l}\text { Undulating } \\
\text { steep rocky } \\
\text { slope }\end{array}$ & 43-264202 E $4034084 \mathrm{~N}$ & 2,416 & 42 & 12 & 32 & 10 & 3 & 9 \\
\hline $\begin{array}{l}\text { 23, Molikhoo, Lonkho } \\
\text { Terich }\end{array}$ & $\begin{array}{l}\text { Rocky steep } \\
\text { slope }\end{array}$ & $43-263107$ E $4035160 \mathrm{~N}$ & 2,435 & 29 & & 41 & & & \\
\hline $\begin{array}{l}\text { 24, Molikhoo, Parsan } \\
\text { Ghari }\end{array}$ & Rock crevice & $42-756321$ E $3991898 \mathrm{~N}$ & 2,722 & 21 & & 31 & & & \\
\hline 25, Molikhoo, Qaqlasht & $\begin{array}{l}\text { Rocky steep } \\
\text { slope }\end{array}$ & $43-258385$ E $4020630 \mathrm{~N}$ & 2,294 & 61 & 31 & 11 & & 5 & 9 \\
\hline $\begin{array}{l}\text { 26, Torikhoo, Sherjoli } \\
\text { Shagram }^{2}\end{array}$ & $\begin{array}{l}\text { Rocky gentle } \\
\text { slope }\end{array}$ & $42-268641$ E $3996145 \mathrm{~N}$ & 2,325 & 71 & 50 & 18 & & & \\
\hline Total & & & & 608 & 520 & 531 & 92 & 159 & 129 \\
\hline
\end{tabular}

${ }^{1}$ Chitral, Bowes Lyon 890 (BM; all from Ghazanfar \& Nasir, 1986: 80)

${ }^{2}$ Chitral, Turikho river, 9,00o feet, 23 May 1958, J.D.A. Stainton 2505 (isotype RAW; G); Turikho river, Stainton 2449 (RAW; BM) 


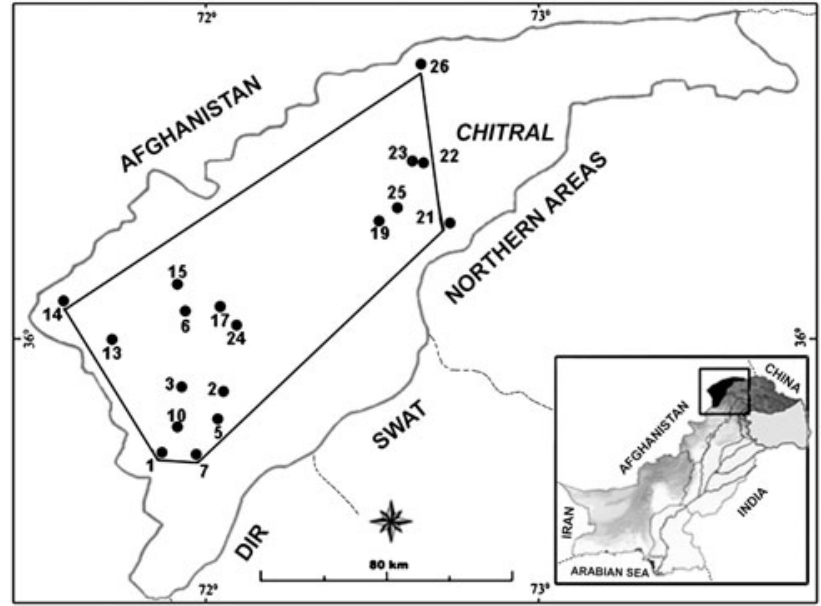

FIg. 1 The 18 numbered locations, of a total of 26 (Table 1), in which we found Silene longisepala in 2007; the polygon delimits the extent of occurrence (see text for details) of the species, which is $3,587 \mathrm{~km}^{2}$. The inset indicates the location of the main map in the North-West Frontier Province of Pakistan.

and 2006, land clearance (Plate $1 \mathrm{~b}$ ) later destroyed the population and we could not locate any plants in 2007.

The people of Chitral use forest trees as fuelwood, particularly during winter, and during our surveys in 2007 we counted a total of 310 felled trees of Pinus gerardiana, Pinus wallichiana, Picea smithiana, Fraxinus excelsior, Betula utilis and Juniperus excelsa in the habitat of S. longisepala, awaiting collection.

We calculated the extent of occurrence and area of occurrence to be 3,587 and $104 \mathrm{~km}^{2}$, respectively, with a total of 531 individuals in 18 localities in 2007, our most recent survey (Fig. 1). Based on this low population size and apparent decline (from 620 individuals in 2005) we recommend that the species should be categorized as

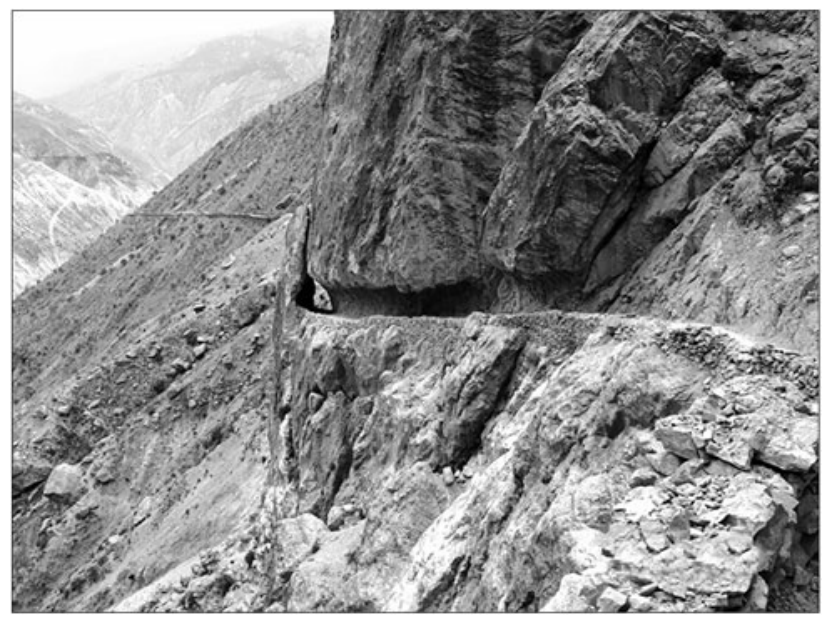

Plate 2 Road construction is in some cases destroying the habitat of S. longisepala, illustrated here in Bakhtoli Gol (Location 15), an important locality for the species (Fig. 1, Table 1).
Endangered on the IUCN Red List based on the criteria (IUCN, 2001) Brab(ii,iii,iv,v)+2ab(ii,iii,iv,v); C2a(i).

\section{Discussion}

Adequate plant collections with good notes of field observation can play a critical role in assessing the conservation status of species, in setting conservation priorities and monitoring population changes (Burgman et al., 1995; MacDougall et al., 1998; Funk et al., 1999; Steege et al., 2000; Golding \& Smith, 2001; Hedenas et al., 2002; Schatz, 2002; Willis et al., 2003; Ungricht et al., 2005). However, various collection biases (such as collections having been made in accessible areas) may lead to misinterpretation, and it is possible that populations documented in herbarium collections may no longer exist. In particular, conservation assessments based principally on herbarium collections may be misleading (Randrianasolo et al., 2002). This is especially true for a relatively inaccessible area such as Chitral. Our surveys of S. longisepala over 3 consecutive years, however, demonstrated the value of longterm field monitoring.

The major threat to S. longisepala is habitat loss from expansion of agriculture on marginal land. Such land clearance results in considerable soil erosion because of the generally steep topography of this mountainous area. We observed that the uppermost soil layer in such areas is usually lost within a few years and the land abandoned. In some localities, however, S. longisepala is fortuitously protected by the general inaccessibility of its habitat. There is no legal framework in Pakistan for the protection of rare and endemic plant taxa on private lands and therefore ex situ conservation may be required for narrow endemics such as S. longisepala. In addition, the Ministry of Environment should require ecological impact assessments before issuing permits for road construction.

The fragmentation of the distribution of $S$. longisepala appears to be a characteristic typical of narrow endemics (Ashton, 1981; Fenu et al., 2011; Martinell et al., 2011). Such species are susceptible to extinction from a variety of causes but especially from the destruction of their habitat (Lande, 1988; Romeo et al., 1994; Schemske et al., 1994; Bernardos et al., 2006).

Our methodology in this study, in which we combined detailed field surveys with monitoring, could form a model for conservation research on rare and endemic plant taxa in Pakistan and elsewhere. In Pakistan this approach needs to be repeated for other species, and particularly for the endemic plant taxa.

\section{Acknowledgements}

The article is part of the $\mathrm{PhD}$ research of HA. The Higher Education Commission of Pakistan is acknowledged for financing the project. 


\section{References}

Ahmad, S., Mian, O., Hai, A.A., Khurshid, N., Qadir, A.R. \& Noor-Un-Nisa (2005) Pakistan: mangroves. In The Root Causes of Biodiversity Loss (eds A. Wood, P. Stedman-Edwards \& J. Mang), pp. 255-281. Earthscan, London, UK.

Alam, J. \& Ali, S.I. (2009) Conservation status of Astragalus gilgitensis Ali: a critically endangered species in Gilgit district, Pakistan. Phyton, 48, 211-223.

Ali, H. \& Q aiser, M. (2010a) Contribution to the Red List of Pakistan: case study of Astragalus gahiratensis. Pakistan Journal of Botany, 42, 1523-1528.

Ali, H. \& Q aiser, M. (2010b) Contribution to the Red List of Pakistan: case study of Gaillonia chitralensis (Rubiaceae). Pakistan Journal of Botany, Special Issue (S.I. Ali Festschrift), 42, 205-212.

A LI, S.I. (2000) Impact of environmental degradation on biodiversity. The Proceedings of the Pakistan Academy of Sciences, 37, 93-97.

A LI, S.I. (2008) Significance of flora with special reference to Pakistan. Pakistan Journal of Botany, 40, 967-971.

ALI, S.I. \& QAISER, M. (1986) A phytoecographical analysis of the phanerogams of Pakistan and Kashmir. Proceedings of the Royal Society, Edinburgh, 89B, 89-101.

Anon. (1998) District Census Report of Chitral. Pakistan Census Organization, Islamabad, Government of Pakistan.

Anon. (2000) Biodiversity Action Plan for Pakistan: Framework for Conserving Our Natural Wealth. IUCN, Rawalpindi, Pakistan.

Ashton, P.S. (1981) Techniques for the identification and conservation of threatened species in tropical forests. In The Biological Aspects of Rare Plant Conservation (ed. H. Synge), pp. 155-164. John Wiley, New York, USA.

Bernardos, S., Amado, A. \& Amich, F. (2006) The narrow endemic Scrophularia valdesii Ortega-Olivencia \& Devesa (Scrophulariaceae) in the Iberian Peninsula: an evaluation of its conservation status. Biodiversity and Conservation, 15, 4027-4043.

Bramwell, D., Raven, P.H. \& Synge, H. (2002) Implementing the global strategy for plant conservation. Plant Talk, 30, 32-37.

Burgman, M.A., Grimson, R.C. \& Ferson, S. (1995) Inferring threat from scientific collections. Conservation Biology, 9, 923-928.

Callmander, M.W., Schatz, G.E. \& Lowry, II, P.P. (2005) IUCN Red List assessment and the Global Strategy for Plant Conservation: taxonomists must act now. Taxon, 54, 1047-1050.

Eberhardt, E., Dickore, W.B. \& Miehe, G. (2006) Vegetation of Hunza Valley: diversity, altitudinal distribution and human impact. In Karakorum in Transition: Culture, Development and Ecology in the Hunza Valley (ed. H. Kreutzmann), pp. 109-122. Oxford University Press, Karachi, Pakistan.

Fenu, G., Mattana, E. \& Bacchetta, G. (2011) Distribution, status and conservation of a Critically Endangered, extremely narrow endemic: Lamyropsis microcephala (Asteraceae) in Sardinia. Oryx, 45, 180-186.

Funk, V.A., Zermaglio, M.F. \& NASIR, N. (1999) Testing the use of specimen collection data and GIS in biodiversity exploration and conservation decision making in Guyana. Biodiversity and Conservation, $8,727-752$.

Ghazanfar, S. \& Nasir, Y.J. (1986) Caryophyllaceae. In Flora of Pakistan (eds E. Nasir \& S.I. Ali), pp. 1-125. Department of Botany, University of Karachi, Karachi, Pakistan.

Golding, J.S. \& SMITH, P.P. (2001) A 13-point flora strategy to meet conservation challenges. Taxon, 50, 475-478.

Hedenas, L., Bisang, I., Tehler, A., Hamnede, M., Jaederfelt, K. \& ODELVIK, G. (2002) A herbarium-based method for estimates of temporal frequency changes: mosses in Sweden. Biological Conservation, 105, 321-331.
IвRAR, M. (2003) Conservation of indigenous medicinal plants and their traditional knowledge found in moist temperate Himalayas, Pakistan. PhD thesis, Department of Biological Sciences, Quaid-i-Azam University, Islamabad, Pakistan.

IUCN (2000) Pakistan Protected Areas System Review and Action Plan. Imprint, Rawalpindi, Pakistan.

IUCN (2001) 2001 IUCN Red List Categories and Criteria (Version 3.1). IUCN, Gland, Switzerland, and Cambridge, UK. Http://www.redlist.org/info/categories_criteria2001.html [accessed 13 April 2009].

IUCN (2010) 2010 IUCN Red List of Threatened Species v. 2010.4. $\mathrm{Http}: / /$ www.iucnredlist.org [accessed 20 January 2011].

Lande, R. (1988) Genetics and demography in biological conservation. Science, 241, 1455-1460.

MacDougall, A.S., Loo, J.A., Clayden, S.R., Goltz, J.G. \& Hinds, H.R. (1998) Defining conservation priorities for plant taxa in southern New Brunswick, Canada, using herbarium records. Biological Conservation, 86, 325-338.

Martinell, M.C., López-Pujol, J., Blanché, C., Molero, J. \& SÀEZ, L. (2011) Conservation assessment of Aquilegia paui (Ranunculaceae): a case study of an extremely narrow endemic. Oryx, 45, 187-190.

Nasir, Y.J. (1991) Threatened plants of Pakistan. In Plant Life of South Asia, Proceedings of the International Symposium (eds S.I. Ali \& A. Ghafaar), pp. 229-234. Department of Botany, University of Karachi, Karachi, Pakistan.

Prance, G.T., Beetje, H., Dransfield, J. \& Johns, R. (2000) The tropical flora remains undercollected. Annals of the Missouri Botanical Garden, 87, 67-71.

Randrianasolo, A., Miller, J.S. \& Consiglio, T.K. (2002) Application of IUCN criteria and Red List categories to species of five Anacardiaceae genera in Madagascar. Biodiversity and Conservation, 11, 1289-1300.

Raunkiaer, C. (1934) The Life Form of Plants and Statistical Plant Geography. Clarendon Press, Oxford, UK.

Romeo, M.I., Ramil, P. \& Rubinos, M. (1994) Conservation status of Eryngium viviparum Gay. Acta Botanica Gallica, 151, $55-64$.

Schatz, G.E. (2002) Taxonomy and herbaria in service of plant conservation: lessons from Madagascar's endemic families. Annals of the Missouri Botanical Garden, 89, 145-152.

Schemske, D.W., Husband, B.C., Ruckelshaus, M.H., Goodwillie, C., PArker, I.M. \& Bishop, J.G. (1994) Evaluating approaches to the conservation of rare and endangered plants. Ecology, 75, 584-606.

Schickhoff, U. (2006) The forest of Hunza Valley: scarce resources under threat. In Karakorum in Transition: Culture, Development, and Ecology in the Hunza Valley (ed. H. Kreutzmann), pp. 123-144. Oxford University Press, Oxford, UK.

Sheikh, K., Ahmad, T. \& Khan, M.A. (2002) Use, exploitation and prospects for conservation: people and plant biodiversity of Naltar valley, north-western Karakorum, Pakistan. Biodiversity and Conservation, 11, 715-742.

Steege, H., Jansen-Jacobs, M.J. \& Datadin, V.K. (2000) Can botanical collections assist in a National Protected Area Strategy in Guyana? Biodiversity and Conservation, 9, 215-240.

The World Bank (2011) Population Growth (Annual \%). Http:// data.worldbank.org/indicator/SP.POP.GROW [accessed 16 June 2011].

Ungricht, S., Rasplus, J.-Y. \& Kjellberg, F. (2005) Extinction threat evaluation of endemic fig trees of New Caledonia: priority assessment for taxonomy and conservation with herbarium collections. Biodiversity and Conservation, 14, 205-232. 
WALTER, K.S. \& GILLET, H.J. (eds) (1998) 1997 IUCN Red List of Threatened Plants. World Conservation Monitoring Centre, Cambridge, UK, and IUCN, Gland, Switzerland.

Willis, F., Moat, J. \& Paton, A. (2003) Defining a role for herbarium data in Red List assessments: a case study of Plectranthus from eastern and southern tropical Africa. Biodiversity and Conservation, 12, 1537-1552.

\section{Biographical sketches}

HAIDAR Ali is currently carrying out research on extinction risk analysis for plants, and biodiversity monitoring. MUHAMMAD QAISER is the co-editor of the Flora of Pakistan and carries out research on plant diversity and the conservation of the flowering plants of Pakistan. 